\title{
A Research on Implementation of Lean Tools Across Verticals in Manufacturing
}

\author{
Muthukumaran.V, Hariram VR, Padmanabhan.K.K
}

\begin{abstract}
With the rapidly growing demand for products in the market, manufacturing has become a crucial part owing to the value addition that it creates. Customer will opt to go for the manufacturers who provide better value for money which is the very basis of sustainability. Implementing Lean methodology would complement the purpose. Lean methodology basically tries to reduce the waste in the process to finally result in process involving mostly value addition to customer. In other words, Lean means 'producing more and more with less and less resources' using various Lean Tools. There are various Lean tools each meant for a specific objective such as identifying the Non-Value-added Activities, workflow improvement, reduction in the variation of the output, Lead Time reduction and much more. Every manufacturing industry will have a wide-variety of challenges.

This paper attempts to map a high-level picture of the various lean tools used across multifarious domains while attempting to co-relate and compare the choice in a relevant fashion. The entire work is done through analyzing the literatures of the lean researchers and practitioners work. This paper will also help the relevant domain people to choose and to understand the reason for selecting the specific lean tools, while implementing Lean methodology.

Keywords - Lean methodology, Lean tools, Manufacturing, Lean implementation, Lean in Manufacturing verticals, Automotive Industry, Machine tool Industry, Construction Industry, Electronics \& Consumer Product Industry, Process Industry, Textile Industry
\end{abstract}

\section{INTRODUCTION}

In the current industrial trends where competition is how they serve their customers in terms of giving the customer a quality product that would cater the need, reliability of the product, customer friendliness and above all the cost. Market giants have gained their own customer and if any emerging industry has to compete with the giants in the market competition, value to money is essential which can be achieved by doing value added activities for the product or eliminating the non- value added activities / wastes in the process. Lean is one of the most powerful methodology to identify and eliminate the waste. customer with less and less resources so as to fulfill the customer need in the least possible cost by using various tools to identify and eliminate / reduce various wastes in the

Revised Manuscript Received on August 14, 2019.

Muthukumaran.V, Professor, Department of Mechanical Engineering, Kumaraguru College of Technology, Coimbatore, T.N, India. (E-mail: kumarvelu70@hotmail.com)

Hariram VR, Assistant Professor, Department of Mechanical Engineering, SNS College of Technology, Coimbatore, T.N, India. (Email: hariram.mech@gmail.com)

Padmanabhan.K.K, Professor, Department of Mechanical Engineering, Karpagam University, Coimbatore, T.N, India.(E-mail: drkkpadmanabhan@gmail.com) immense, the very sustainability of any company is based on

Lean is all about producing more and more value to the

process. Any activity / operation that customers are willing to pay for is a Value Added Activity and any activity / operation that consumes resources but don't create any value is a Waste [1].

According to K.Liker, seven main types of wastes were identified as a part of the Toyota Production System. [2]

1. Transport

2. Inventory

3. Motion

4. Waiting

5. Over-processing

6. Overproduction

7. Defects

\section{LEAN TOOLS IN BRIEF}

There are various lean tools of which notably some tools are commonly employed [3], $5 S$ :

- Sort (Removing all unnecessary items from the location)

- Set In Order (Everything has a place and everything in its place)

- Shine (Clean and inspect work area)

- Standardize (Standardize the processes used to above)

- Sustain (Sustain the developed processes by selfdiscipline of the workers).

Value Stream Mapping (VSM) - A complete representation of the value-added and non-value added activities across the defined area / service.

Andon - A Visual feedback system for the shop floor to signposts production status, alert for support when needed, and empower operators to halt the production process.

Just -In-Time (JIT) - Pull parts through production Just in the time when the customer needs by avoiding excess inventory.

Kaizen - A strategic continuous improvement tools where workforce collaborate proactively to achieve regular, incremental improvements in the process.

SMED (Single Minute Exchange of Die) - Reduce setup changeover time.

Kanban - A technique for regulating the supply of components is using instruction cards which are sent along the production line and in some cases within the factory and with outside suppliers and customers. A pull system to be precise.

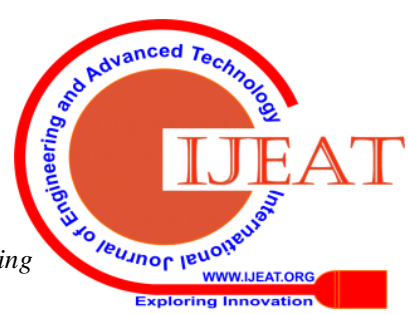


Heijunka (Level Scheduling) - A technique for process improvement to balance the supply - demand patterns and eliminate manufacturing waste by having smaller batches by sequencing (mixing) product variant within the same process.

Jidoka - Simple autonomation, forcing things to happen as they should i.e., machines having one particular function without any thing possibly going wrong.

Standardized work - A document that captures the Manufacturing procedures in turn to identify the best practices. It has to be a live document with a ease to change.

TPM (Total Productive Maintenance) - A high-level approach to carry proactive and preventative maintenance to maximize the operational time of equipment by minimizing the down time.

Visual Management - Visual management systems empowers the employees to be cognizant with production procedures and further significant information for effective work.

\section{METHODOLOGY}

Various literatures, research reports and journal articles of the researchers and practitioners are referred to write this paper. Snow bowling method of literature survey was also made in addition to the traditional method. A detailed literature search was made to find the relevant articles in lean implementation and usage of tools across each manufacturing vertical. All the relevant articles are analyzed in the paradigm purview of lean tools used on a high level.

\section{LITERATURE SURVEY}

Literature articles are referred for each manufacturing vertical in the context of Lean implementation in manufacturing, the sub - domain level vision in Automotive Industry, Machine tool Industry, Construction industry, Electronics \& Consumer Products industry, Process Industry $\&$ Textile Industry.

\section{A. Lean in Automotive Industry}

Aditya Sharma [4] checked the application of VSM in Indian auto component Industry and proved it to be much beneficial since it helped to identify all types of lean waste and improvement areas where other tools for improvements. Also it was found that top management involvement is one of the important factors for successful lean implementation.

Kumar et. al [5] used VSM, Kaizen, Kanban, 5S and Total Productive Maintenance (TPM) for reducing the defects in the automobile accessories manufactured by a diecasting process. It was also found Top Management support for the production managers and training for the employees paved the way to successful deployment of the lean principles in the organization. TPM with Lean sigma framework resulted in increased production and, at the same time, increased employee morale and job satisfaction. [5]

Hariram VR , V. Muthukumaran (2017), used VSM to identify reduce the non-value added time in an auto component industry and implemented the layout out change to improve the productivity. Also in an another lean implementation, plant layout was changed and OEE was improved. [6] [7]
Nallusamy, Dr \& Ahamed (2017), used various tools such as 5S, VSM, Line balancing, TPM, Kanban in order to reduce the non-value-added activities and to improve the process cycle efficiency. It is stated that majority of the Lean tools are used in the Automotive industry. [8]

\section{B. Lean in Machine tool Industry}

R.G. Priyaadarshini et al [9] carried out a research on the lean implementation in machine tool industry and found $66 \%$ of the companies use TPM and Standardized work, 55 $\%-60 \%$ of the companies use Batch production, JIT and continuous improvement, $45 \%$ of the companies use $5 \mathrm{~S}$ and Single piece production, 30-40\% of the companies use Kanban and VSM.

Eswaramoorthi et al [10] conducted a study and examined the extent of practicing the lean manufacturing within Indian machine tool industries. The 50 to $60 \%$ of the companies use work standardization, Value Stream Mapping, cross functional teams, Poka-yoke, Root Cause Analysis and FMEA, 40 to $50 \%$ of the companies use $5 \mathrm{~S}$, process capability, multi skill workers, Kaizen, Ergonomic Work station, QFD, 30 to $40 \%$ of the companies deploy DFMA, TPM/ OEE, JIT, Kanban, Visual Management, one piece flow, QMS, TQM, SMED and Andon.

\section{Lean in Construction Industry}

Ankomah E. N. et al., [11] made a research where they found that 5S, 5 Why's, Kaizen, Poka-Yoke, Heijunka, VSM, Kanban, Ishikawa diagram, Business Information Modelling and SMED.

Tejas Vidhate and Ashwini salunkhe (2018), stated that the important lean tools that are widely used in the construction industry are VSM, Pull system, JIT, Kanban, 5S and Last Planner System (LPS). [12]

\section{Lean in Electronics \& Consumer Products Industry}

Subashini et al (2012), used VSM as a major tool in a kitchenware manufacturing industry for VSM identifies the wastes in the entire stream of the value chain and paved the way to identify the improvement areas which through proper implementing leads to reduction in the lead time and Work in progress Inventory. [13]

Laoha et. al (2015), conducted a case study on a small scale electronics industry and compared with the Garment and Shoe industry in which Kanban, Visual Management, 5S, Machine cell Layout, Line balancing, Quick changeover, Multi skill workers, Standard operation procedure, PokaYoke, Total Preventive Maintenance, Muda, Kaizen, Policy Deployment were found to be the important tools. [14]

Devarani Devi et al (2013) studied the application of lean Manufacturing Methodologies in Indian Electronics Manufacturing Industry and listed JIT (Just in Time), Six Sigma, Jidoka and Kaizen are the most widely used lean manufacturing tools in Indian electronics manufacturing. [15] 


\section{E. Lean in Process Industry}

According to Abdulmalek et. al [16] and Abdulmalek et al. [17], TPM, SMED, VSM, 5S, Visual Control are the major lean tools used across the Sheet and Metal - Process industry. Chowdary and George, [18] through their research, validated that 5S, Poka-Yoke, Andon, Work Cells, Prior Inspection were the lean tools widely used in the chemical Industry.

Abhishek Kumar Singh et al.,[19] used of information system along with lean manufacturing to reduce the waste in the process industry in which he opted to use the lean tools (VSM, TPM, Pull system, Kanban, SMED and production levelling) to reduce the lead time.

Hariram VR and V. Muthukumaran [20], used VSM to identify the improvement areas in a foundry and implemented 5S \& Layout optimization for the lead time reduction.

\section{F. Lean in Textile Industry}

Hodge, et al., [21] adapted lean manufacturing principles to the textile industry and found that the major lean tools used include are Andon, VSM and 5S.

Based on the research done by Chethan Kumar and N.V.R. Naidu [22], the five most adopted lean tools in the textile industry are Kaizen, VSM, 5S, Six sigma and Kanban. These reason being all these tools require less time to be planned and implemented. In contrast, Poka-yoke needs more time and financial aid as well to implement mistake-proofing features. Similarly, JIT is a long term lean tool which needs the change in whole of the organizational system. Further after the sustenance with the basic lean tools, TPM can be implemented to prevent the breakdowns of equipment or facilities.

\section{RESULTS AND DISCUSSION}

It is observed that several tools are used in almost all the industries extensively and with Top priority. It is vivid that 5S, VSM, Kanban, Kaizen, Six sigma and standardized work are too common across the industries. Moreover, the selection of lean tool for implementation is a crucial part owing to the fact the outcome of the tool has to align with the vision of the industry since that top management commitment is important for a successful implementation.

The Table I and II comprehends the list of widely implemented lean tools in the manufacturing sectors.

TABLE I Widely implemented Lean Tools across manufacturing verticals (Automotive, Machinetool and Electroincs \& Consumer Products)

\begin{tabular}{|l|l|l|}
\hline $\begin{array}{c}\text { Automotive } \\
\text { Industry }\end{array}$ & \multicolumn{1}{|c|}{$\begin{array}{c}\text { Machine tool } \\
\text { Industry }\end{array}$} & $\begin{array}{c}\text { Electronics \& } \\
\text { Consumer } \\
\text { Product Industry }\end{array}$ \\
\hline $5 \mathrm{~S}$ & TPM & VSM \\
\hline VSM & $\begin{array}{l}\text { Standardized } \\
\text { work }\end{array}$ & Kanban \\
\hline Kanban & VSM & $\begin{array}{l}\text { Visual } \\
\text { Management }\end{array}$ \\
\hline Kaizen & $\begin{array}{l}\text { Batch } \\
\text { production }\end{array}$ & $5 \mathrm{~S}$ \\
\hline TPM & JIT & Machine cell \\
\hline
\end{tabular}

\begin{tabular}{|l|l|l|}
\hline & & Layout \\
\hline Line Balancing & Kaizen & Line balancing \\
\hline Six sigma & 5 S & Quick changeover \\
\hline OEE & One Piece Flow & $\begin{array}{l}\text { Multi skill } \\
\text { workers }\end{array}$ \\
\hline SMED & Kanban & $\begin{array}{l}\text { Standardized } \\
\text { work }\end{array}$ \\
\hline Batch production & $\begin{array}{l}\text { Root Cause } \\
\text { Analysis }\end{array}$ & Poka-Yoke \\
\hline $\begin{array}{l}\text { Standardized } \\
\text { work }\end{array}$ & FMEA & TPM \\
\hline $\begin{array}{l}\text { Machine cell } \\
\text { Layout }\end{array}$ & Six sigma & Kaizen \\
\hline Line balancing & Kanban & JIT (Just in Time) \\
\hline Poka-Yoke & & Six Sigma \\
\hline JIT & & Jidoka \\
\hline $\begin{array}{l}\text { Layout } \\
\text { optimisation }\end{array}$ & Kaizen \\
\hline
\end{tabular}

TABLE II Widely implemented Lean Tools across manufacturing verticals (Construction, Process and Textile)

\begin{tabular}{|l|l|l|}
\hline $\begin{array}{l}\text { Construction } \\
\text { Industry }\end{array}$ & Process Industry & $\begin{array}{l}\text { Textile } \\
\text { Industry }\end{array}$ \\
\hline 5 S & TPM & VSM \\
\hline 5 Whys & SMED & 5S \\
\hline Kaizen & VSM & Andon \\
\hline Poka-Yoke & 5 S & Kaizen \\
\hline Heijunka & Visual Control & Six sigma \\
\hline VSM & Poka-Yoke & Kanban \\
\hline Kanban & Andon & Poka-Yoke \\
\hline $\begin{array}{l}\text { Root cause } \\
\text { Analysis }\end{array}$ & Pull system & JIT \\
\hline $\begin{array}{l}\text { Business } \\
\text { Information } \\
\text { Modelling }\end{array}$ & Kanban & TPM \\
\hline SMED & Heijunka & \\
\hline & $\begin{array}{l}\text { Layout } \\
\text { optimisation }\end{array}$ & \\
\hline
\end{tabular}

\section{CONCLUSION}

The work is to understand the relation between the lean tools and the implementation in the Manufacturing industry in sub-domain paradigm. It is clear that most of the verticals implemented the basic lean tools and a few of the giants opt to go further more but the co-relation between the tools selection for implementation is specific to the firm's problem and vision on a closer look. But on a higher level we could see that Automotive Industry and Electronics industry effectively use Lean methodology and no wonder owing to their huge requirement demand compared to the other verticals. 


\section{REFERENCES}

1. P.Womack, J., T.Jones, D. \& Roos, D., "The Machine that Changed the World" 2nd ed. s.l.:Harper Perennial., 1990.

2. K.Liker, J., "The Toyoya Way - 14 Management Priniciples" 2 ed. Tata McGraw-Hill Edition, 2004.

3. Mandar M. Sumant \& Shashank J. Thanki, "Identify the Lean Tool for Different Industrial Sectors in India", IJEDR, Volume 2, Issue 2., 2014

4. Aditya Sharma, Naga Vamsi Krishna Jasti, "Lean manufacturing implementation using value stream mapping as a tool: A case study from auto components industry", International Journal of Lean Six Sigma, Vol. 5 Issue: 1, pp.89-116, 2014. https://doi.org/10.1108/IJLSS-04-2012-0002

5. Kumar, M., Antony, J. Singh, R. K. Tiwari, M. K. and Perry, D., "Implementing the Lean Sigma framework in an Indian SME: a case study. Production Planning \& Control", 17(4), 407-423, 2006

6. Hariram VR., V. Muthukumaran., "Improving industrial performance of an SME", Accent Journal of Economics Ecology \& Engineering, vol 2 issue 11, 2017.

7. Hariram VR., V. Muthukumaran., "Implementation of value stream mapping in an SME", Asia Pacific Journal of Research, Vol: I. Issue LIII, July2017, Pg. 265 - 268, 2017.

8. Nallusamy, Dr \& Ahamed M.A., Adil., "Implementation of Lean Tools in an Automotive Industry for Productivity Enhancement - A Case Study. International Journal of Engineering" Research in Africa, 2017. Doi: 29.175-185. 10.4028/www.scientific.net/JERA.29.175.

9. R.G.Priyaadarshini, V.R. Sathish Kumar, S.Aishwarya Rajlakshmi., "Study on lean thinking among MSMEs in the Machine tool sector in India", IOP Conf. Series: Materials Science and Engineering, 2017. doi:10.1088/1757899X/310/1/012091

10. M. Eswaramoorthi, G. R. Kathiresan, P. S. S. Prasad \& P. V. Mohanram., "A survey on lean practices in Indian machine tool industries", Intl Journal of Advanced Manufacturing Technology, 52:1091-1101, 2011.

11. Ankomah E. N., Ayarkwa J. and Agyekum K., "A Theoretical review of lean implementation within construction SMES", ICIDA 2017 - 6th International Conference on Infrastructure Development in Africa, KNUST, Kumasi, Ghana, 2017.

12. Tejas Vidhate, Ashwini salunkhe, "General overview of Lean Management in Construction Industry", International Research Journal of Engineering and Technology (IRJET) Volume: 05 Issue: 07, 2018.

13. Subashini G.S, Mohan Kumar S \& Asaithambi B, "Lean manufacturing approach to improve the performance of kitchenware manufacturing industry in Chennai (India) ", International Journal of Mechanical And Production Engineering Research And Development (Ijmperd ) Issn 2249-6890 Vol.2, Issue 3. Pg 56-66, 2012.

14. Laoha, Chanchai \& Sukto, Seekharin., "Lean assessment for manufacturing of small and medium enterprises (SMEs): A case study of electronics industry in the Northeast of Thailand". KU Engineering Journal. 2015.

15. Devarani Devi, Sorokhaibam Khaba and Pranab Kumar Dan, "A Study on Application of lean Manufacturing Methodologies in Indian Electronics Manufacturing Industry" Ningombam, Research Journal of Engineering Sciences, Vol. 2(5), 11-14, May 2013.

16. Abdulmalek, F. A., and Rajgopal. J., "Analyzing the Benefits of Lean Manufacturing and Value Stream Mapping via Simulation: A Process Sector Case Study. International Journal of Production Economics", 107 (1): 223-236, 2007.

17. Abdulmalek, F. A., Rajgopal, J. and Needy, K. L., "A Classification Scheme for the Process Industry to Guide the Implementation of Lean, Engineering Management Journal", 18:2, pp.15-25, 2006.

18. Chowdary, B. V. and George, D., "Improvement of manufacturing operations at a pharmaceutical company: A lean manufacturing approach. Journal of Manufacturing Technology Management", 23(1) pp. 56-75, 2012.

19. A. K. Singh, R. S. Sisodiya, R. Bisht, And A. Maheshwari, "Use Of Information System And Lean Manufacturing To Reduce The Waste In The Process Industry", Int. J. Electron. Comput. Sci. Eng., Vol. 2, No. 2, Pp.778-786.

20. Hariram VR., V. Muthukumaran., "Implementation of lean tools in an SME", International Journal of World Research, Vol: I, Issue XXXV, pg. 43 - 49, 2017

21. Hodge, G. L., Ross, K. G., Joines, J. A. and Thoney, T., "Adapting lean manufacturing principles to the textile industry. Production Planning \& Control", 22(3), pp. 237-247, 2011.

22. C. S. C. Kumar And N. V. R. Naidu, "A Survey on Awareness Of Lean Manufacturing Concepts In Indian Garment Manufacturing Industries,” Int. Conf. Challenges Oppor. Mech. Eng. Ind. Eng. Manag. Stud., Pp. 783-785. July, 2012. 